\title{
Fabrication and characterization of the Ti-Ca-P composites by vacuum sintering
}

\author{
Dibakar Mondal ${ }^{1}$, Swapan Kumar Sarkar ${ }^{1}$, Dong-Won Lee ${ }^{2}$, Young-Seon Lee ${ }^{2}$, Byong-Taek Lee ${ }^{*}$ \\ ${ }^{1}$ Department of Biomedical Engineering and Materials, College of Medicine, Soonchunhyang University, Chungnam, Korea; \\ ${ }^{2}$ Department of Materials Processing, Korea Institute of Materials Science, Changwon, Kyungsangnam-Do, Korea. \\ Email: $\underline{1 b t @ \text { sch.ac.kr }}$
}

Received 14 February 2011; revised 25 April 2011; accepted 23 May 2011.

\begin{abstract}
Using Ti and biphasic calcium phosphate (BCP) powders, Ti-Ca-P composites which contained 0 - 30 vol.\% BCP powders initially, were fabricated by vacuum sintering at two different sintering temperatures, $1300^{\circ} \mathrm{C}$ and $1400^{\circ} \mathrm{C}$. Detailed microstructural characteristics of the resulting composites were investigated. Mechanical properties like compressive strength, Vickers hardness were evaluated and they showed decreasing trend with the increasing initial BCP content. The $x$-ray diffraction (XRD) profiles revealed that extensive chemical reaction occurred and the initial $\mathrm{BCP}$ was degraded and formed $\mathrm{CaO}, \mathrm{TiO}_{2}$, TiP, $\mathrm{CaTiO}_{3}$. However, the cell viability by MTT assay and cell proliferation behavior through one cell morphology analysis showed excellent increasing trend in biocompatibility which makes this materials suitable for hard tissue aid material. And the composite containing 30 vol.\% BCP content with Ti sintered at $1400^{\circ} \mathrm{C}$ showed excellent biocompatibility with the Vickers Hardness value $108.8 \mathrm{HV}$ and the compressive strength value $303.7 \mathrm{MPa}$.
\end{abstract}

Keywords: Ti; Calcium Phosphate; Biocompatibility; Bio-Ceramic

\section{INTRODUCTION}

Biocompatible metals such as $\mathrm{Ti}$ and its alloys, $\mathrm{Co}-\mathrm{Cr}$ alloys are still the most preferred implant materials for applications that require load bearing conditions, whether it is in dense form or porous. Titanium and its alloys are corrosion resistant, biocompatible, and selfpassivating materials that have a much lower elastic modulus than Co-Cr alloys and stainless steel. The mechanical properties of titanium and its alloys are good enough for load-bearing implants, but their biocompatibility is much lower than that of calcium phosphate ce- ramics [1,2]. In addition, the interface between titanium and host bone is a simple interlocking bonding owing to the bio-inert nature of titanium metal, which can lead to the loosening of the implant and the eventual failure of implantation [3]. The lack of biological bonding between the metal and host bone can cause wear and associated debris which can lead to particle induced inflammation. The implantation of metal in place of the damaged bone can cause the stress shielding effect, due to the dissimilarity of elastic modulus between bone and the implant materials, which weakens new bone formation and causes severe damages to the whole bone structure in the long run. The skeleton grows more bone tissue in regions where the load on the skeleton is large and the net result is a more closely packed and stronger skeleton that has the strength to sustain the increased load. In areas with diminished load, the skeleton retains only enough bone tissue necessary to sustain the diminished load. Thus, the skeleton in unloaded areas is weaker [4-6]. Surgeons believe that stress shielding is harmful because the weaker skeleton may fracture. The stress shielding effect depends on the difference between the stiffness of the shaft component and the stiffness of the bone. This only can be avoided by matching the elastic modulus of the implant and bone closely. The problems with titanium metals are obvious and only could be addressed with a systemic approach to incorporate features to improve the biocompatibility and modify the mechanical properties.

$\mathrm{BCP}$, which is a mixture of Hydroxyapatite, $\mathrm{Ca}_{10}\left(\mathrm{PO}_{4}\right)_{6}(\mathrm{OH})_{2}$ and Tri Calcium Phosphate, $\mathrm{Ca}_{3}\left(\mathrm{PO}_{4}\right)_{2}$, has a similar crystallographic structure to bones mineral phase. Several studies have demonstrated that BCP is biocompatible with hard tissues and exhibits osseoconductive properties [5-9]. It is also well known that BCP forms a direct bond with surrounding tissue after bone implantation. However, its poor mechanical properties, especially the fracture toughness less by an order of 
magnitude, are the most serious obstacles for applications as load-bearing implants [10].

Many efforts have been made to improve the mechanical properties of Hydroxyapatite (HAp) [11,12] and the biological properties of titanium and its alloys [13, 14]. Achieving a good combination of the bioactivity of HAp and the favorable mechanical properties of metals are considered a promising approach to fabricate more perfect biomedical devices for load-bearing applications in hard tissue engineering. This could be achieved by using appropriate metallic reinforcing materials with hydroxyapatite [15-17]. Functionally graded materials consisting of metallic and ceramic components [18] have been shown to improve the properties of several systems such as medical implant devices.

Several studies have examined the potential of coating of Hydroxyapatite on $\mathrm{Ti}$ with or without combination of Ti to improve the biocompatibility of the metallic system in terms of biological fixation with the host site. Several methods of coating $\mathrm{Ti}$ have been developed such as plasma spraying, dip-spin, electrochemical etc. [19-22]. However, coating $\mathrm{Ti}$ is complex because the bonding strength of the interface of $\mathrm{Ti}$ and $\mathrm{BCP}$ is very low. Therefore, it is very difficult to prepare a uniform coating on an implant with a complex structure using this technique. The most widely used coating method is plasma spray coating, which severely damages the Hydroxyapatite [19-21]. BCP and Ti duplex metal-matrix composites can be viewed as a potential alternative but there are also some unique problems using this approach. Due to severe oxidation of titanium in air, sintering of the Ti-BCP composites has to be done in vacuum or under the protection of an inert atmosphere. However, under such sintering conditions, dehydration and decomposition temperatures of HAp will decrease remarkably [23], which decreases its mechanical properties as well as the excellent biocompatibility of the HAp is lost. However, a comprehensive investigation is still to be reported with the aim to incorporate HAp in titanium matrix with a nano-structured HAp phase inclusion and the improvement of biocompatibility along with the modification of mechanical properties with in favorable range of magnitude.

In this study, Ti-BCP composites were fabricated using the vacuum sintering method to combine the bioactivity of BCP and the mechanical properties of titanium. Two sintering temperatures, $1300^{\circ} \mathrm{C}$ and $1400^{\circ} \mathrm{C}$, were used to investigate the sintering behaviors. In addition, four compositions at each sintering temperatures were examined; pure Ti or $0 \% \mathrm{BCP}$ as the controls, 10 vol. $\%$ BCP, 20 vol.\% BCP and 30 vol.\% BCP. These experiments were conducted to investigate changes in the properties of the composite as a function of BCP content.
Especially using MTT assay and observation of single cell growth the cell viability and biocompatibility of Ti-Ca-P based composites were investigated.

\section{MATERIALS AND METHODS}

\subsection{Preparation of the Composite}

The BCP powder was prepared at room temperature by mixing calcium nitrate tetrahydrate $\left(\mathrm{Ca}\left(\mathrm{NO}_{3}\right)_{2} \cdot 4 \mathrm{H}_{2} \mathrm{O}\right)$ (Samchun Chemicals, 98.5\% pure) and ammonium phosphate dibasic $\left(\left(\mathrm{NH}_{4}\right)_{3} \mathrm{PO}_{4} \cdot 2 \mathrm{H}_{2} \mathrm{O}\right)$ (Samchun Chemicals, $98.5 \%$ pure) in an ultrasonic bath [24]. $\mathrm{NH}_{4} \mathrm{OH}$ was added to the solution to bring the $\mathrm{pH}>9$ and the sample was ultrasonciated for $4 \mathrm{hrs}$. The solution was then allowed to precipitate for $24 \mathrm{hr}$. Then, the precipitated BCP was washed to remove $\mathrm{NH}_{4} \mathrm{OH}$ and filtrated. After filtration the cake was dried at $80^{\circ} \mathrm{C}$ for $72 \mathrm{hr}$ in an oven and then crushed. The BCP powder was then calcined at $750^{\circ} \mathrm{C}$ for $2 \mathrm{hr}$. Commercially pure titanium powder (-325 mesh, 99.5\%, Alfa Aesar, USA) and BCP were mixed with alcohol and ball milled for $24 \mathrm{hr}$. Four different compositions were fabricated; pure Ti powder, 10 vol.\% BCP, 20 vol.\% BCP and 30 vol.\% BCP powder with Ti. The mixture was then dried at $80^{\circ} \mathrm{C}$ for $3 \mathrm{hr}$. For the characterization of microstructure and material properties, pellets of $1.3 \mathrm{~cm}$ diameter were made in a hydraulic pressure unit (Carver Inc., USA) with 5 tons force. Then, the composite pellets were sintered in vacuum at a temperature of $1300^{\circ} \mathrm{C}$ and $1400^{\circ} \mathrm{C}$ for $1 \mathrm{hr}$.

\subsection{Characterization}

The density of the composites was measured using the Archimedes method. The Vickers' hardness was measured using a hardness testing machine (Microvicker, Akashi, Japan) and the compressive strength was measured using universal testing machine (Unitech TM, R\&B, Korea). The microstructure of the composites was characterized using a Scanning Electron Microscope (JSM6701F, JEOL Ltd, Japan). In addition, the composites composition and crystal structure of composites were determined by X-Ray diffraction (Miniflex II, Rigaku, Japan).

\subsection{In Vitro Study}

The in vitro properties of the composite were characterized by cytotoxicity test for L929 cell line with a MTT (3-(4,5-Dimethylthiazol-2-yl)-2,5-diphenyltetrazolium bromide, a tetrazole) solution and the cell morphology of individual cells using MG63 cell line.

BCP-Ti composites pellets were first chemically etched with a $20 \% \mathrm{H}_{2} \mathrm{SO}_{4}$ solution for 5 minutes in an ultrasonic bath. Then, they were cleaned with acetone, alcohol and deionized water sequentially in an ultrasonic bath for 5 minutes each. The pellets were placed in fal- 
con tubes and sterilized in an autoclave.

The pellets were then submerged in $12 \mathrm{ml}$ solution of Roswell Park Memorial Institute medium (RPMI). The mixture is then incubated $5 \% \mathrm{CO}_{2}$ atmospheres for 72 $\mathrm{hrs}$ in a shaking incubator. After that medium was filtrated and the extract was taken in $50 \mathrm{ml}$ falcon tube. Previously cultured L929 cells were seeded into 96-well microtiter plates (NunclonTM, Nunc, Wiesbaden, Germany) at a density of $7 \times 10^{4}$ cells/well. After washing with PBS the extract and medium solution were pour into the well and moved those in $\mathrm{CO}_{2}$ incubator for 72 hrs. After that the medium was removed and in each well $20 \mu \mathrm{lof} 5 \mathrm{mg} \cdot \mathrm{ml}^{-1}$ MTT was added including one set of wells with MTT but no cells (control). Then Incubated for 3.5 hours at $37^{\circ} \mathrm{C}$ in culture hood media was removed carefully. With adding $150 \mu \mathrm{l}$ MTT solvent the plate was covered with $\mathrm{Al}$ foil and agitates cells on orbital shaker for $15 \mathrm{~min}$, then the absorbance was read at $590 \mathrm{~nm}$ using an HP 8453 spectrophotometer.

For one cell morphology the MG63 cells were seeded onto the composite pellets in a 24-multiwell plate at a final density 10,000 cells $\cdot \mathrm{cm}^{-2}$. After $1 \mathrm{hr}$ and $24 \mathrm{hrs}$, the media was removed and after dehydratationin ethanol solutions of $75 \%, 90 \%, 95 \%$ and $100 \%$ specimens were fixed with $4 \%$ glutaraldehyde in PBS ( $\mathrm{pH} 7.2$ ) and keep at room temperature for drying. After drying the samples were sputter-coated with Pt. The surface of the specimens was finally examined with backscattered (BSE) mode and secondary electrons (SE) modeby scanning electron microscopy (SEM) under a voltage of $15 \mathrm{kV}$.

\section{RESULTS}

\subsection{Microstructure and Morphologies of Ti-Ca-P Composites}

SEM images of sintered composites body had shown in Fig.1, as the amount of initial BCP in composites increases so does the porosity in the composites. This trend was common for both of the sintering temperature of $1300^{\circ} \mathrm{C}$ and $1400^{\circ} \mathrm{C}$ as shown in Figures $1(\mathbf{a}-\mathbf{d})$, respectively. From the SEM images, we could easily see that the titanium surface was barely visible except for the polished surface.

\subsection{Phase Composition of the Composites}

The SEM microstructure and energy dispersive X-ray spectroscopy (EDS) profile of the Ti-10\% BCP composite sintered at $1400^{\circ} \mathrm{C}$ shown in Figure 2. As shown in Figure 2(b), in selected point Pon the titanium metal surface, significant amounts of titanium were observed as expected. In addition, in point $\mathrm{Q}$ contained more $\mathrm{Ca}$ and $\mathrm{P}$ (Figure 2(c)); however, a significant amount of Ti was
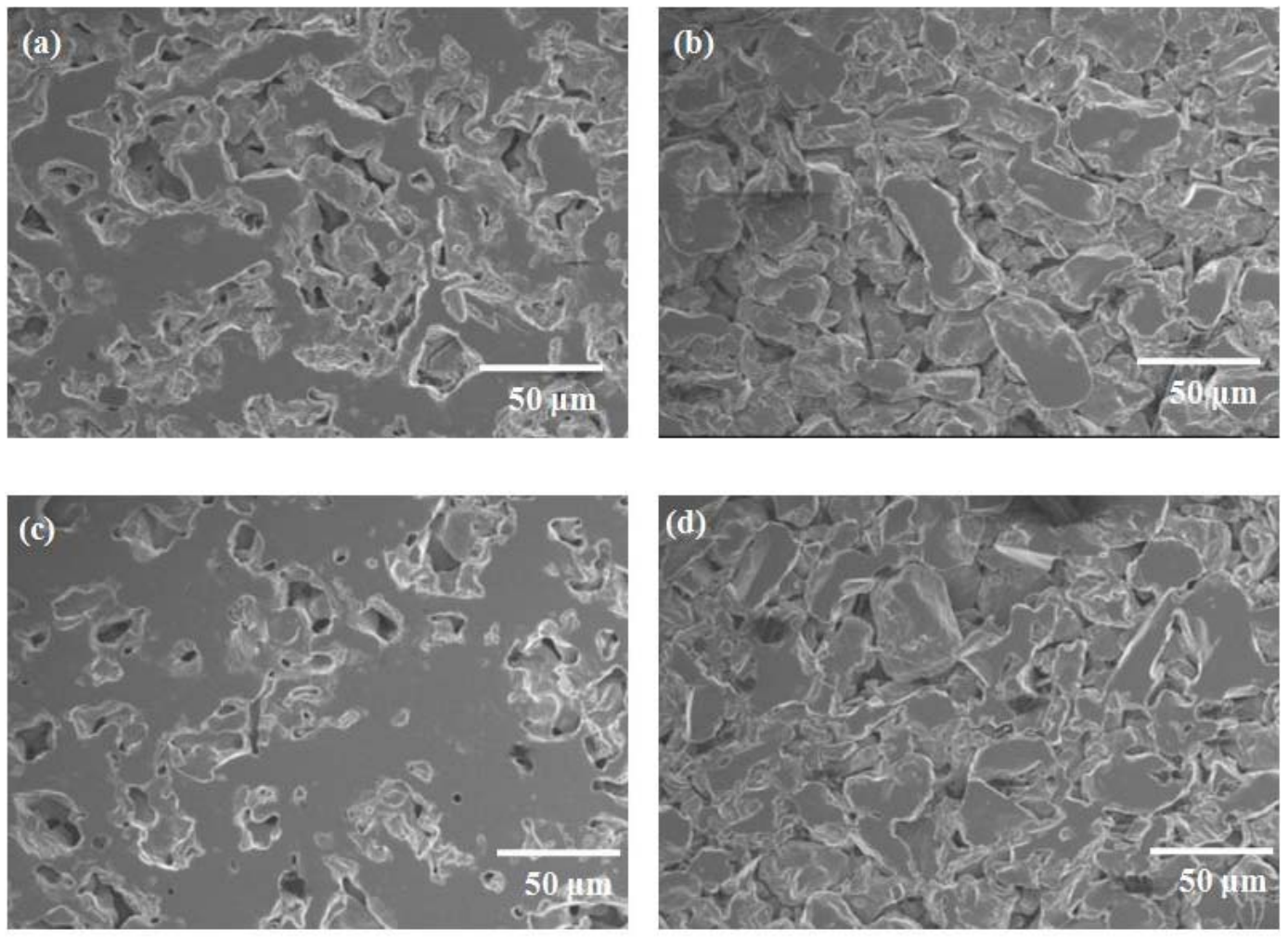

Figure 1. SEM morphologies of (a) $10 \%$ BCP-Ti; (b) $30 \%$ BCP-Ti vacuum sintered at $1300^{\circ} \mathrm{C}$ and (c) $10 \%$ BCP-Ti; (d) $30 \%$ BCP-Ti vacuum sintered at $1400^{\circ} \mathrm{C}$. 

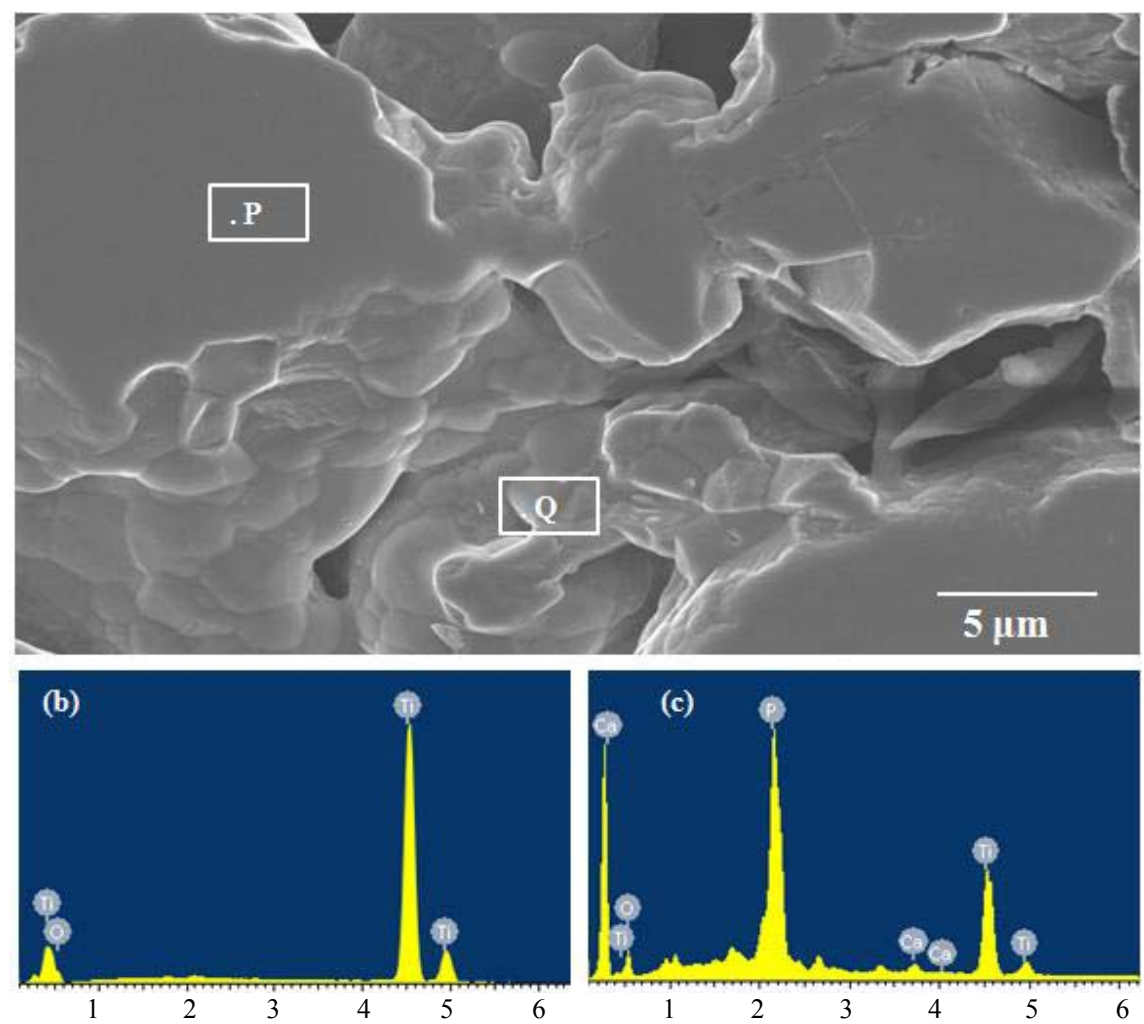

Figure 2. (a) SEM image of a small area of 10\% BCP-Ti based composites surface sintered at $1400^{\circ} \mathrm{C}$ and Energy dispersive spectroscopy (EDS) profiles of (b) point $\mathrm{P}$ on titanium surface and (c) point $\mathrm{Q}$ on Ca-P surface.

also there, which revealed that $\mathrm{Ti}$ in the composite body got reacted with the initial BCP phase, which was the reason for the decomposition of the calcium phosphate phase. Ti reacted with $\mathrm{BCP}$ and formed $\mathrm{TiO}_{2}$, TiP and $\mathrm{CaTiO}_{3}$. By analyzing the $\mathrm{x}$-ray diffraction data (XRD) in Figure 3, the phase can be mostly detected. From Figure 3(a) for pure $\mathrm{Ti}$, no $\mathrm{TiO}_{2}$ or $\mathrm{CaO}$ or $\mathrm{CaTiO}_{3}$ was observed. But for $90 \%$ Ti with 10\% initial BCP and both for vacuum sintered at (b) $1300^{\circ} \mathrm{C}$ and (d) $1400^{\circ} \mathrm{C}$, some amount of $\mathrm{TiO}_{2}, \mathrm{CaO}$ and $\mathrm{CaTiO}_{3}$ had formed. In addition, for $70 \%$ Ti with $30 \%$ initial BCP, the amount of all these components increased. At all compositions and both sintering temperatures, no BCP phase was detected (for BCP major peak occurs at $2 \theta$ value of 31 ).

\subsection{Mechanical Characteristics of the Composites}

As shown in Figure 4(a), the density of the $\mathrm{Ti}$ based composites decreasedat increasing initial BCP content for vacuum sintered composites both at $1300^{\circ} \mathrm{C}$ and $1400^{\circ} \mathrm{C}$. Pure $\mathrm{Ti}$ had almost the same value as the theoretical value near $4.50 \mathrm{~g} \cdot \mathrm{cm}^{-3}$. The hardness and compressive strength also showed the same tendency, there was a decrease in the mechanical properties at higher initial BCP contents as shown in Figures 4(b) and (c).
From these figures it can be seen that at the same initial Ti-BCP composition, composites sintered at $1400^{\circ} \mathrm{C}$ had better mechanical properties than composites sintered at $1300^{\circ} \mathrm{C}$ due to enhanced densification at higher temperature, although the composition reacted at high temperature to form different reaction product and the initial BCP phase was almost entirely disappeared. For pure titanium, this effect was not significant. The hardness value was drastically fallen after introducing the ceramic phase but kept steady afterwards with minor declination with the increased BCP content. Compressive strength value showed steadily declination as the initial BCP content was increasing.

\subsection{In Vitro Experiments}

To evaluate the cytotoxicity of the composites, cell viability and cell proliferation on the composites were determined through in vitro experiments with MTT assay and by examining the morphology of surface grown individual cells. These experiments were conducted with the composites sintered at a temperature of $1400^{\circ} \mathrm{C}$. It was expected that the $70 \% \mathrm{Ti}$ based composite would show the best results relative to the other compositions because of high initial Ca-P content. As expected, after 60 minutes of incubation, the cells on the $70 \%$ Ti com- 


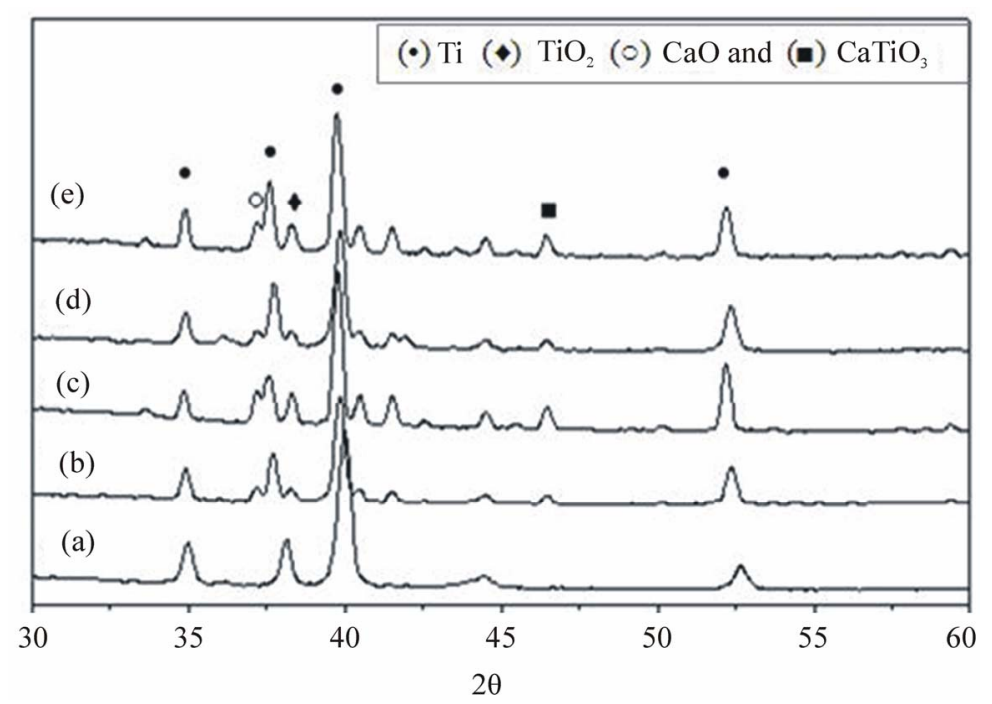

Figure 3. XRD pattems of (a) pure Ti sintered at $1400^{\circ} \mathrm{C}$, (b) $10 \% \mathrm{BCP}-\mathrm{Ti}$ and (c) $30 \%$ BCP-Ti sintered at $1300{ }^{\circ} \mathrm{C}$, (d) $10 \%$ BCP-Ti and (e) $30 \%$ $\mathrm{BCP}-\mathrm{Ti}$ sintered at $1400^{\circ} \mathrm{C}$. Unmarked peaks are TiP.

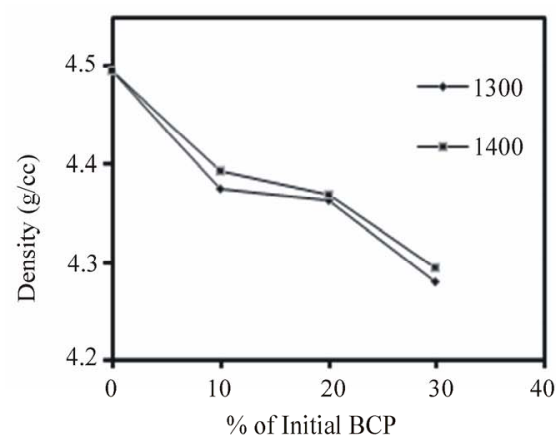

(a)

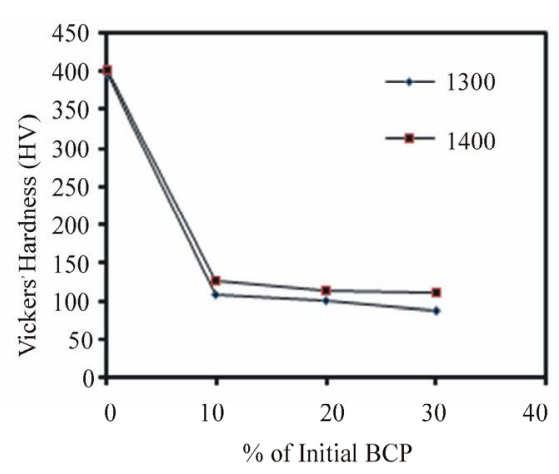

(b)

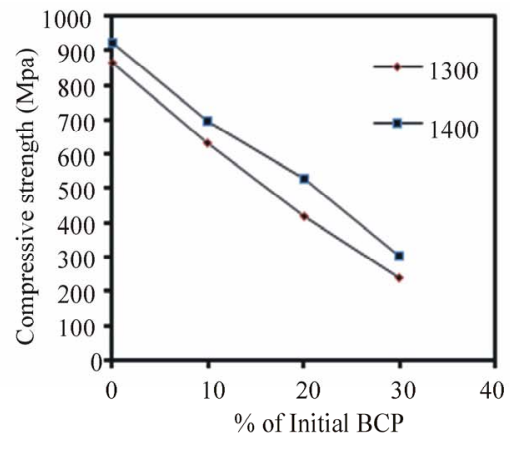

(c)

Figure 4. Density, (b) Vikers' Hardness and (c) compressive strength of Ti-BCP composites at two different sintering temperatures.

posites had divided daughter cells were observed in the SEM images; however, no daughter cells were observed on the $80 \%$ Ti based composites and others.

\section{DISCUSSION}

Prior to mixing, the biphasic calcium phosphate and titanium powders consisted of different particle size which made a non uniform mixing with a bimodal particle distribution with two sharp peaks (Figure 1). BCP powder consisted of nano size particles $(<100 \mathrm{~nm}$ particle size $)$ with spherical morphology [25] and the Ti powder consisted of micro size particle (less than $43 \mu \mathrm{m}$ ) with irregular spongy shape [26]. The nano sized BCP covered the much larger Ti particles and make a soft coating like layer. This prevented the grain diffusion of the $\mathrm{Ti}$ and sintering was hindered. The BCP particles themselves were sintered in the mean time and the inter-particular space of the $\mathrm{Ti}$ particles remained barely unaltered to make the residual pores. However there were some necking zones among the Ti particles that facilitate sintering.

The XRD (Figure 3) and EDS (Figure 2) profiles indicated that there was a reaction between titanium and BCP. And BCP degraded into $\mathrm{CaTiO}_{3}, \mathrm{CaO}, \mathrm{TiO}_{2}$ and TiP. The reaction [27] between the titanium and $\mathrm{BCP}$ is,

$$
\begin{aligned}
\mathrm{Ti}+\mathrm{Ca}_{10}\left(\mathrm{PO}_{4}\right)_{6}(\mathrm{OH})_{2} \rightarrow & \mathrm{CaTiO}_{3}+\mathrm{CaO}+\mathrm{TiO}_{2}+\mathrm{TiP} \\
& +\mathrm{H}_{2} \mathrm{O} .
\end{aligned}
$$

Soas desired, no Hydroxyapatite or tri-calcium phosphate was found in the final sintered sample as shown in the XRD profiles of Figure 3. The SEM images of the composite bodies as shown in Fig.1demonstrated that the surface of the titanium particles was degraded. The titanium particles were wrapped by the other materials produced after the sintering. As the BCP concentration increased so did the porosity and surface degradation. This is due to the thicker covering of the Ti particles by in- 
creased amount of BCP, which reduced the necking zone of Ti.

The phases of the sintered composites did not change significantly at the two different vacuum sintering temperature $1300^{\circ} \mathrm{C}$ and $1400^{\circ} \mathrm{C}$. In the XRD patterns (Figure 3), small amounts of $\mathrm{CaO}, \mathrm{TiO}_{2}$, TiPand $\mathrm{CaTiO}_{3}$ were observed in the $90 \% \mathrm{Ti}$ based composites sintered at both $1300^{\circ} \mathrm{C}$ and $1400^{\circ} \mathrm{C}$. However, for the $70 \% \mathrm{Ti}$ based composites, the amount of these compounds increased at both sintering temperatures. Both HAp and TCP degraded and the disproportionate peak intensity between the metal and nonmetal composition made it difficult to detect the phases.

The mechanical properties of $\mathrm{TiO}_{2}$ as shown in figure 4 vary drastically from $\mathrm{Ti}$. Ti, being a metal has superior strength value and fracture toughness and microstructural defects like cracks or pores does not affect the properties overwhelmingly. Composites were denser at higher sintering temperature of $1400^{\circ} \mathrm{C}$ than $1300^{\circ} \mathrm{C}$. The density of commercially pure $\mathrm{Ti}, \mathrm{TiO}_{2}, \mathrm{CaTiO}_{3}$ and TiP are $4.506 \mathrm{~g} \cdot \mathrm{cm}^{-3}, 4.23 \mathrm{~g} \cdot \mathrm{cm}^{-3}, 3.98 \mathrm{~g} \cdot \mathrm{cm}^{-3}$ and 4.08 $\mathrm{g} \cdot \mathrm{cm}^{-3}$ respectively. So that with increasing BCP content in the composites the density decreased very rapidly. The Vickers Hardness showed a steep decline with the introduction of BCP powder from $400 \mathrm{HV}$ to about its one third values, but did not change drastically with the increasing of BCP. This is because of the introduction of porosity with the addition of BCP phase. In this study the $70 \%$ Ti based composites sintered at $1400^{\circ} \mathrm{C}$ showed Vickers hardness value $108.8 \mathrm{HV}$ and compressive strength value $303.7 \mathrm{MPa}$. These values are closer to the natural bones mechanical properties than that of the pure Ti. For a human cortical bone Vickers hardness and compressive strength are approximately $40.4 \mathrm{HV}$ and
138 - $224 \mathrm{MPa}$, [28] respectively.

For a biomaterial, good cell viability is the most important pre-condition. MTT assay for the fabricated materials shown in Figure 5 revealed that all the composites composition exhibited good cell viability. MTT was performed with L929 cell line which is a fibrosarcoma cell line. $70 \%$ Ti based composite showed most cell viability than any other composition with more than $80 \%$ absorbance for 100\% extract as shown in Figure 5. From the XRD data we knew that with increasing BCP the amount of $\mathrm{TiO}_{2}, \mathrm{CaO}$ and $\mathrm{CaTiO}_{3}$ also increased and from the MTT assay graph the cell compatibility also increased with increasing of initial BCP concentration. This infers that even after reaction was occurred, the composites remained biocompatible. The interface between the implant and the host bone is one of the most important issues for biomaterials used in hard tissue repair applications. The bonding type is considered to be a vital criterion for evaluating the biocompatibility and bioactivity of biomaterials. When the morphology of individual cells that had been incubated with the composites for 60 minutes was analyzed, all composites except pure Ti displayed a good cell proliferation and cell attachment behavior as shown in Figure 6. On pure Ti surface cells cannot proliferate in such short time [29]. Osteosarcoma MG63 cell line was used for one cell morphology analysis. The cells were bound to the composites surfaces and proliferated well. After 60 minutes of cell seeding the filopodial activity for $100 \%$ and $80 \% \mathrm{Ti}$ based composites were same as shown in Figure 6(a) and (b). But in 70\% Ti case composites (Figure 6(c)) cells started to divide into new daughter cells and migrated. Filopods of cells in $70 \%$ Ti based composites surface were most elongated. And one day after the cells

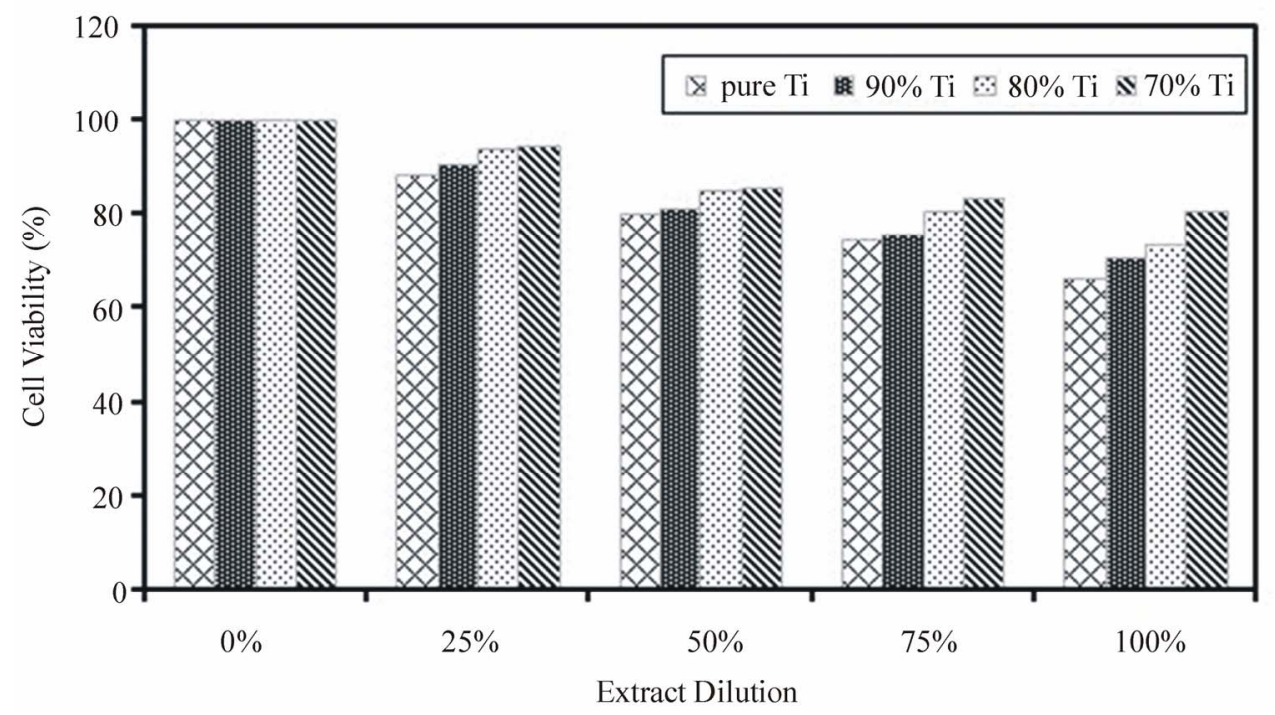

Figure 5. MTT assay results of composites vacuum sintered at $1400^{\circ} \mathrm{C}$. 

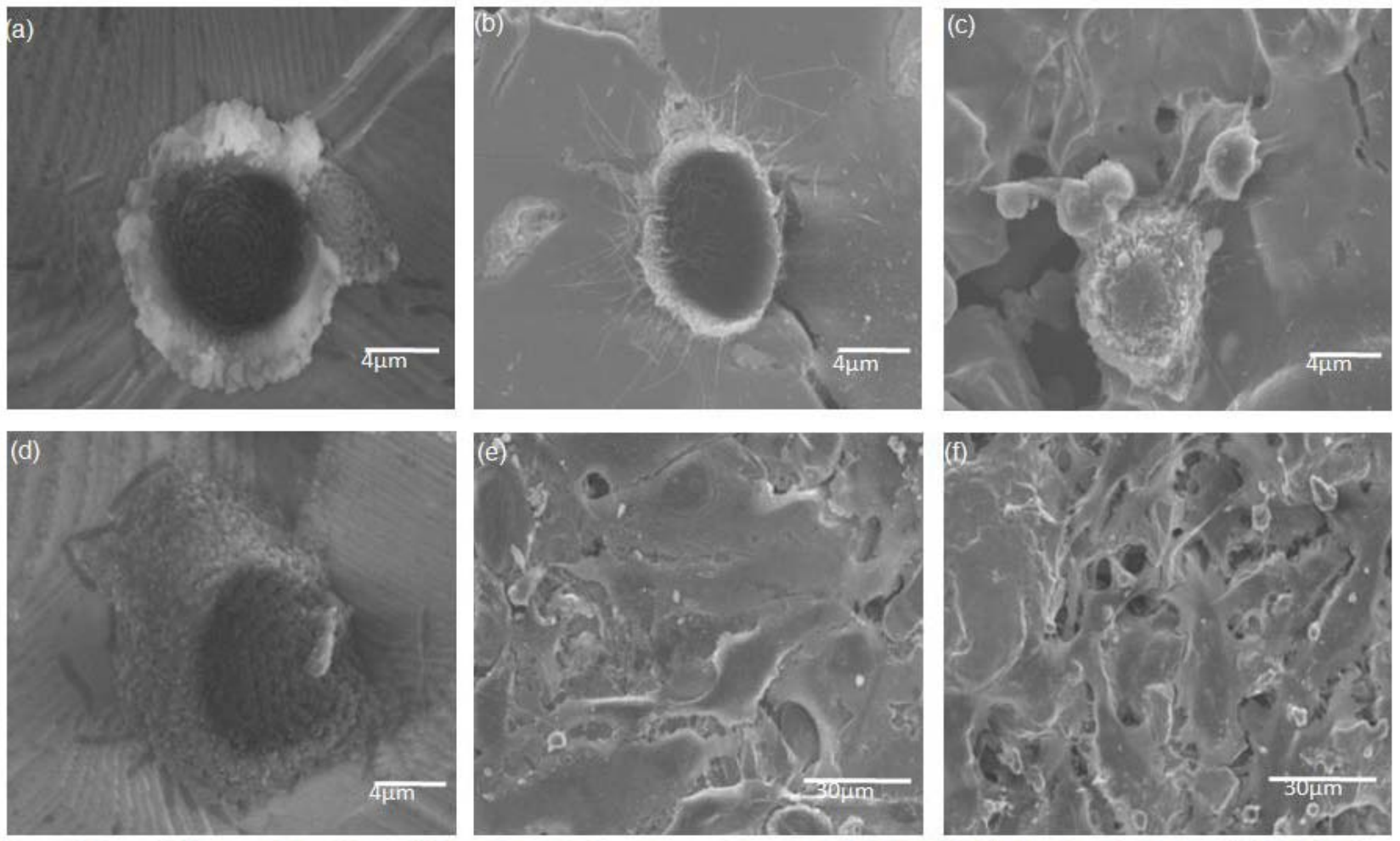

Figure 6. Cell morphology on the surfaces of Ti based composites vacuum sintered at $1400^{\circ} \mathrm{C}$ with MG63 cells; (a) pure Ti, (b) $20 \%$ BCP-Ti, (c) 30\% BCP-Ti and after 1 hrs of cell seeding and (d) pure Ti, (e) 20\% BCP-Ti and (f) $30 \%$ BCP-Ti after 24 hrs of cell seeding.

were seeded, the surface of the $70 \%$ Ti based composite body was completely covered with cells that wereproliferating (Figure 6(f)). In the case of pure Ti, no significant change in cell attachment was observed for one day after cell seeding.

From the above discussion it can be drawn that the mechanical properties shows better resemblance to that of the cortical bone for the fabricated $70 \%$ Ti composites compared to the pure titanium metal or even with that of the titanium alloy. Moreover, the biocompatibility of the $70 \% \mathrm{Ti}$ also showed remarkable improvement over that of the pure Ti as shown in the MTT assay experiment and cell proliferation after 24 hours. These two facts indicate that the $70 \% \mathrm{Ti}$ composites can be a potential candidate for better hard tissue implant material for load bearing condition. This would potentially minimize the risk of stress shielding effect that is caused by the implantation of pure Ti or its alloy or any other metallic systems.

Although the initial materials were not fully preserved after carrying out the fabrication process and a whole new group of reaction products appeared, the biocompatibility of the fabricated materials were not compromised. In contrast to the pure titanium, all the materials had superior cell viability and cell proliferation behavior.
The material was not fully densified as the $\mathrm{CaP}$ phase created a barrier for the Ti particles to sinter. This significantly decreases the mechanical properties of the pure $\mathrm{Ti}$ as shown by the hardness and compressive strength value which was roughly one fourth of the pure metals properties for $70 \% \mathrm{Ti}$ containing composites. However, the values were high enough for the successful application as implant materials.

\section{CONCLUSIONS}

The in vitro bioactivity of $\mathrm{Ti}$ based composite is dependent on their initial composition, i.e. the phase composition of the composites. The bioactivity was in the order of $70 \% \mathrm{Ti}>80 \% \mathrm{Ti}>90 \% \mathrm{Ti}>$ pure $\mathrm{Ti}$. For the $70 \% \mathrm{Ti}$ based composite, the cells started to divide into daughter cells on the composite surfaces within $60 \mathrm{~min}$ utes. In addition, the mechanical properties were suitable enough for use as a load bearing hard tissue implant. The results of this work suggest that the Ti based composites containing $70 \% \mathrm{Ti}$ are potential candidates for load bearing bone replacement applications.

\section{REFERENCES}

[1] Healy, K.E. and Ducheyne, P. (1992) The mechanisms of passive dissolution of titanium in a model physiological 
environment. Journal of Biomedical Materials Research, 26, 319-338. doi:10.1002/jbm.820260305

[2] Nanci, A., Wuest, J.D., Peru, L., Brunet, P., Sharma, V., Zalzal S. and McKee, M.D. (1998) Chemical modification of titanium surfaces for covalent attachment of biological molecules. Journal of Biomedical Materials Research, 40, 324-335.

doi:10.1002/(SICI)1097-4636(199805)40:2<324::AID-J BM18>3.0.CO;2-L

[3] Albrektsson, T. and Hansson, H.A. (1986) An ultrastructural characterization of the interface between bone and sputtered titanium or stainless steel surfaces. Biomaterials, 7, 201-205. doi:10.1016/0142-9612(86)90103-1

[4] Damien C.J. and Persons, J.R. (1992) Bone graft and bone graft substitutes: A review of current technology and applications. Journal of Applied Biomaterials, 2, 187- 208. doi:10.1002/jab.770020307

[5] Hench, L.L. (1999) Bioactive Glasses and Glass-Ceramics. Materials Science Forum, 293, 37-64. doi:10.4028/www.scientific.net/MSF.293.37

[6] McGrory, B.J., Morrey, B.F., Cahalan, T.D. and Cabanela M.E. (1995) Effect of femoral offset on range of motion and abductor muscle strength after total hip arthroplasty. Journal of Bone and Joint Surgery, 77, 865-869.

[7] Elliott, J.C., Mackie P.E. and Young, R.A. (1973) Monoclinic Hydroxyapatite. Science, 108, 1055-1057. doi:10.1126/science.180.4090.1055

[8] Hong, L., Xu H.C. and De Groot, K. (1992) Tensile strength of the interface between hydroxyapatite and bone. Journal of Biomedical Materials Research, 26, 7-18. doi:10.1002/jbm.820260103

[9] Edwards, J.T., Brunski, J.B. and Higuchi, H.W. (1997) Mechanical and morphologic investigation of the tensile strength of a bone hydroxyapatite interface. Journal of Biomedical Materials Research, 36, 454-468. doi:10.1002/(SICI)1097-4636(19970915)36:4<454::AID -JBM3>3.0.CO;2-D

[10] Gautier, S., Champion, E., Bernache-Assollant D. and Chartier T., (1999) Rheological characteristics of aluminia platelet-hydroxyapatite composite suspension. Journal of the European Ceramic Society, 19, 469-477. doi:10.1016/S0955-2219(98)00224-6

[11] Kong, Y., Kim, S., Kim, H. and Lee, I. (1999) Reinforcement of hydroxyapatite bioceramics by addition of $\mathrm{ZrO}_{2}$ coated $\mathrm{Al}_{2} \mathrm{O}_{3}$. Journal of the European Ceramic Society, 82, 2963-2968. doi:10.1111/j.1151-2916.1999.tb02189.x

[12] Li, J., Hermansson L. and Soremark, R. (1993) High strength biofunctional zirconia: Mechanical properties and static fatigue behaviour of zirconia-apatite composite. Journal of Materials Science: Materials in Medicine, 4, 50-54. doi:10.1007/BF00122977

[13] T. Kokubo, T. Matsushita and H. Takadama (2007) titania-based bioactive materials. Journal of the European Ceramic Society, 27, 1553-1558. doi:10.1016/j.jeurceramsoc.2006.04.015

[14] Vehof, J.W.M., Spauwen P.H.M. and Jansen, J.A. (2000) Bone formation in calcium-phosphate-coated titanium mesh. Biomaterials, 21, 2003-2009. doi:10.1016/S0142-9612(00)00094-6

[15] Miyazaki, T., Kim, H.M., Miyaji, F., Kokubo, T. and
Nakamura, T. (1997) Bioceramics 10. Elsevier Science LTD, New York.

[16] Kim, H.M., Miyaji, F., Kokubo, T. and Nakamura, T. (1997) Apatite-forming ability of alkali-treated ti metal in body environment. Journal of the ceramic Society of Japan, 105, 111-116. doi:10.2109/jcersj.105.111

[17] Cortes, D.A., Escobedo, J.C., Nogiwa A. and Munoz, A. (2003) Biomimetic bonelike apatite coating on cobalt based alloys. Materials Science Forum, 442, 61-66. doi:10.4028/www.scientific.net/MSF.442.61

[18] Aboudi J., Pindera, M.-J. and Arnold, S.M. (2001) Linear thermoelastic higher-order theory for periodic multiphase materials, Journal of Applied Mechanics, 68, 697-707. doi:10.1115/1.1381005

[19] De Groot, K., Geesink, R., Klein C. and Serekian, P. (1987) Plasma sprayed coatings of Hydroxyapatite. Journal of Biomedical Materials Research, 21, 13751381. doi: $10.1002 / \mathrm{jbm} .820211203$

[20] Yang, Y.C. (2007) Influence of residual stress on bonding strength of the plasma-sprayed hydroxyapatite coating after the vacuum heat treatment, Surface and Coatings Technology, 201, 7187-7193. doi:10.1016/j.surfcoat.2007.01.027

[21] Chen C.C. and Ding, S.J. (2006) Effect of heat treatment on characteristics of plasma sprayed hydroxyapatite coatings. Materials Transactions, 47, 935-940. doi:10.2320/matertrans.47.935

[22] Yang, X.D., Lu, X., Zhang, Q.Y., Zhang, X.D., et al. (2007) BCP coatings on pure titanium plates by CD method. Materials Science and Engineering C, 27, 781786. doi:10.1016/j.msec.2006.08.011

[23] Ducheyne P. and Hasting, G.W. (1984) Metal and Ceramic Biomaterials. CRC Press, Boca Raton, 144-166.

[24] Byong-Taek, L., Min-Ho, Y., RajatKanti, P., Kap-Ho, L. and Ho-Yeon, S. (2007) In situ synthesis of spherical BCP nanopowders by microwave assisted process. Materials Chemistry and Physics, 104, 249-253. doi:10.1016/i.matchemphys.2007.02.009

[25] Cao, L., Zhang, C. and Huang, J. (2005) Synthesis of hydroxyapatite nanoparticles in ultrasonic precipitation. Ceramics International, 31, 1041-1044. doi:10.1016/j.ceramint.2004.11.002

[26] Choi, M. G. et al. (2005) Effects of titanium particle size on osteoblast functions in vitro and in vivo. PNAS, 102, 4578-4583. doi:10.1073/pnas.0500693102

[27] Ning C.Q. and Zhou, Y. (2004) On the microstructure of biocomposites sintered from $\mathrm{Ti}$, HA and bioactive glass. Biomaterials, 25, 3379-3387. doi:10.1016/j.biomaterials.2003.10.017

[28] Reilly D.T. and Burstein, A.H. (1975) The elastic and ultimate properties of compact bone tissue. Journal of Biomechanics, 8, 393-396. doi:10.1016/0021-9290(75)90075-5

[29] Schmidt, C., Ignatius A.A. and Claes, L.E. (2001) Proliferation and differentiation parameters of humanosteoblasts on titanium and steel surfaces. Journal of Biomedical Materials Research, 54, 209-215. doi:10.1002/1097-4636(200102)54:2<209::AID-JBM7>3 .0.CO;2-7 